\title{
The Role of Slovak Airports in Tourism Development
}

\author{
Marian Gúčik, ${ }^{1 *}$, Milota Vetráková ${ }^{1}$, and Matúš Marciš ${ }^{1}$ \\ ${ }^{1}$ Matej Bel University in Banská Bystrica, Faculty of Economics, 97590 Tajovského 10, Banská \\ Bystrica, Slovakia
}

\begin{abstract}
Tourism is in a close connection with the transport operations and as such develop thanks to various forms of transport. A large role in the effects on the growth potential of international tourism play the individual countries, whose task is to promote the development of air transport, and hence boosting the national economy and many of its areas. The article presents the evaluation of the air transport infrastructure in Slovakia, which is a prerequisite for the development of tourism. It contains theoretical backroad of air transport service and analyses of the role of Slovak airports in tourism development. The article deals with the assumption that the transport accessibility of a country with a regular air service is the basis for international transport. The aim of the article is to evaluate the role of Slovak airports in terms of passenger transport and tourism development. Its emphasizes the development of air transport in Slovakia, analyses airports performances and investments in the air transport infrastructure. Secondary sources were used and processed by selected mathematical and statistical methods of descriptive statistics.
\end{abstract}

\section{Introduction}

Transport or transportation is one of the most important preconditions for the economic development of the region. From the historical point of view, the development of transport was the main reason for traveling and tourism. The relationship between tourism and transport is mutual. Tourism has a number of requirements on transport, especially on the capacity and frequency of transport, on the distance and speed, safety and comfort, and last but not least on the price of transport [1]. In tourism, the quality of transport infrastructure and the transport accessibility of the regions and cities has an important role because it influences the decision-making of visitors, destination choice and can also attract investors [2]. Transport also provides opportunities for visitors at the destinations, between attractions and hiking trails, etc. Not only public transport (road, rail, air and water), but also individual passenger transport, is important in tourism.

Particularly in international tourism, the air transport is generally accepted as the fastest option. Air transport represents the economic and social development of the state and, at the same time, it is one of the indicators of the living standards of its inhabitants. The task of air transport is to ensure fast, safe and quality transportation of people and goods. A

* Corresponding author: marian.gucik@umb.sk 
prerequisite for this is the appropriate infrastructure that allows not only the transportation of goods, but also the transportation of visitors especially in foreign tourism. The air transport cost is significantly affected by transport charges and rates, transport equipment and price of fuels.

The number of air passengers in 2017 internationally exceeded 4 billion. This is 7\% more than in the previous year. The majority of passengers were flying with Ryanair [3]. In tourism, air transport is particularly important for continental and intercontinental transport to long-distant destinations. In addition to the services of airlines, aircraft ground handling services are essential.

An aviation enterprise (airlines or commercial air transport operator) provides flight information, passenger seats available, flight schedules, handling passengers and their baggage before and after arriving, providing on-board services (refreshments and meals, cultural entertainment). Ground handling equipment is part of the airport and provides passengers with luggage storage, gastronomic services, health services, rental cars and goods of various kinds. The international airports, which are usually ports of entry, as are road and rail crossings on a land border, also have passport and customs services.

In 2007, more than half of the world's airline market was dominated by the three global airline alliances - Star Alliance, Oneworld, Sky Team [4]. Accepting global alliance rules bring cost savings and reduces risk to airlines. The aim of the alliance is to simplify and price reduction of services, reduction cost of airfares, traffic on the common lines, which ensures a better capacity utilisation of aircraft, joint handling of passengers, shared services at the airports and co-marketing programs for loyal customers.

In the 90's., there had been a boom of the low-cost airlines, which provide in particular regional transport on a $1.5-2$ hour flights. They fly between the selected destinations, usually to small cheaper airports, prefer the sale of airline tickets over the internet and do not provide any free onboard services. Currently, for example, the Hungarian low-cost airline company Wizz Air has $58 \%$ of income from ticket sales and $42 \%$ from additional services. It is assumed that this proportion will change in favour of the additional charges, which will be the airline subsidising the ticket prices [5].

\section{Aim, material and methodology}

The aim of the paper is to evaluate the role of Slovak airports in terms of passenger transport and tourism development. Its emphasizes the development of air transport in Slovakia, analyses airports performances and investments in the air transport infrastructure. Secondary sources from Statistical office of Slovak Republic, Ministry of Transport and Construction of SR and selected airports were used and processed by mathematical and statistical methods of descriptive statistics.

\section{Results}

After the dissolution of Czech and Slovak Federative Republic (ČSFR), the Slovak Republic remained without a national airline operator. Until 2003, the air transport in Slovakia was provided by the Czechoslovak Airlines (Československé Aerolinie).

\subsection{Domestic airlines after the establishment of the Slovak republic}

In order to provide travel services, several airlines have operated on the Slovak market (Table 1). 
Table 1. Defunct and existing Airlines in Slovakia. Source: [4-6]

\begin{tabular}{|c|c|c|}
\hline Airline & Period & Activity \\
\hline \multicolumn{3}{|c|}{ Defunct airlines } \\
\hline Tatra Air & $1991-1999$ & Scheduled air services \\
\hline Air Slovakia BWJ & $1993-2010$ & Scheduled and non-scheduled air services \\
\hline Slovenské aerolínie & $1995-2007$ & Scheduled and non-scheduled air services \\
\hline Seagle Air & $1995-2009$ & National and international transport \\
\hline Slov Air & $1969-2001$ & Construction work services \\
\hline Sky Europe Airlines & $2001-2009$ & Low-cost scheduled air service \\
\hline Opera Jet & $2007-2014$ & Private air services \\
\hline Danube Vings & $2008-2013$ & Scheduled and non-scheduled air services \\
\hline Samair & $2010-2015$ & Non-scheduled air services \\
\hline Quck Duck Airlines & $2014-2015$ & Aircraft leasing \\
\hline \multicolumn{3}{|c|}{ Existing airlines } \\
\hline Air Transport Europe & $1991-$ & Air Rescue Service \\
\hline Air Explore & $2008-$ & Aircraft leasing \\
\hline $\begin{array}{l}\text { Travel Service Slovakia (or Smart } \\
\text { Wings) }\end{array}$ & $2010-$ & Non-scheduled air services \\
\hline Go2Sky & $2012-$ & $\begin{array}{l}\text { Non-scheduled air services for persons, } \\
\text { cargo and mail air services }\end{array}$ \\
\hline Air Cargo Global & $2013-$ & All-freight air services \\
\hline JetAge & $2013-$ & Aviation school \\
\hline
\end{tabular}

The situation has often changed from year to year. The accession of the Slovak Republic to the European Union in 2004 was associated with the integration of Slovak civil aviation into the organization and regulation of EU air transport policy and with the new opportunities for the local airlines on the international market. The basic objectives of the transport policy of the Slovak Republic were formulated in the 2000 Air Transport Development Concept of the Slovak Republic.

After the establishment of the Slovak Republic, four airlines defunct including Slovak Airlines (Slovenské aerolínie) in 2007, Seagle Air with Sky Europe Airlines in 2009 and Air Slovakia BWJ in 2010. The most frequent cause of airlines defunct in Slovakia was not an insufficient demand for air transport services, but financial problems associated with failure to pay commitments to airports, insurance companies and service providers. Scheduled air services to Slovakia were provided by foreign airline operators, like Czech Airlines (ČSA), Aeroflot, Hemus Air, Tyrolean Airways and Tunisair. These airlines connect Slovakia mainly to their home airports, from where it was possible to travel to other destinations.

Domestic airlines on scheduled flights in 2000 transported only $11 \%$ of passengers and $89 \%$ foreign airlines, most of them Aeroflot and ČSA. From the total number of passengers transported in 2000, 431,183 (19.4\%) travelled non-scheduled flights. These data show that, in addition to the absence of a strong domestic airline operator, foreign airlines were not interested to provide scheduled air connection to the rest of the world. The development of Slovak air transport was a significantly influenced by the importance of Prague Airport, the nearness of the Vienna airport and Budapest.

The situation in the offer of Slovak transport services pointed to the absence of a strong domestic airline, the lack of financial resources and the unfavourable structure of the fleet. Regarding the full liberalization of the market under the Multilateral Agreement on the Establishment of a European Common Aviation Area (ECAA), Slovakia tried to create conditions common to airlines in the EU.

The number of passengers in scheduled air transport from Slovak airports in 2000 is captured in Table 2. 
Table 2. The number of passengers in scheduled air transport from Slovak airports in 2000.

Source: [4]

\begin{tabular}{|c|c|c|}
\hline Airline & $\begin{array}{c}\text { Scheduled air } \\
\text { transport } \\
\text { passengers }\end{array}$ & Share (\%) \\
\hline Domestic & 37,474 & 10.8 \\
\hline Air Slovakia & 25,645 & 7.4 \\
\hline Slovenské aerolínie & 11,829 & 3.4 \\
\hline Foreign & 310,204 & 89.2 \\
\hline ČSA & 136,589 & 44.0 \\
\hline Aeroflot & 152,608 & 49.2 \\
\hline Tyrolean & 10,863 & 3.5 \\
\hline Tunis Air & 6,753 & 2.2 \\
\hline Hemus Air & 1,832 & 0.6 \\
\hline Air Ukrajina & 1,559 & 0.5 \\
\hline Passengers total & 347,678 & 100.0 \\
\hline
\end{tabular}

In order to make the market more accessible and to increase the volume of air transport to Slovakia, it was necessary to make Slovak airports more attractive and to improve the infrastructure for business travellers and foreign tourists. It was expected that strong European airlines and low-cost airlines would be oriented to a more developed air transport market. Therefore, it was intended to connect Slovakia to European catchment areas (hubs) and to establish a network of scheduled air services that would be provided by domestic airlines.

In this context, the role of the State was to create appropriate legal conditions for Slovak airlines to purchase equipment and provide air transport services as well as an appropriate fee policy (airport charges, air service charges) to stimulate the introduction of new air services from Bratislava airport, respectively Košice to European airports.

\subsection{Air transport infrastructure}

The air transport infrastructure in Slovakia currently consists of a sufficiently dense network of airports (Figure 1).

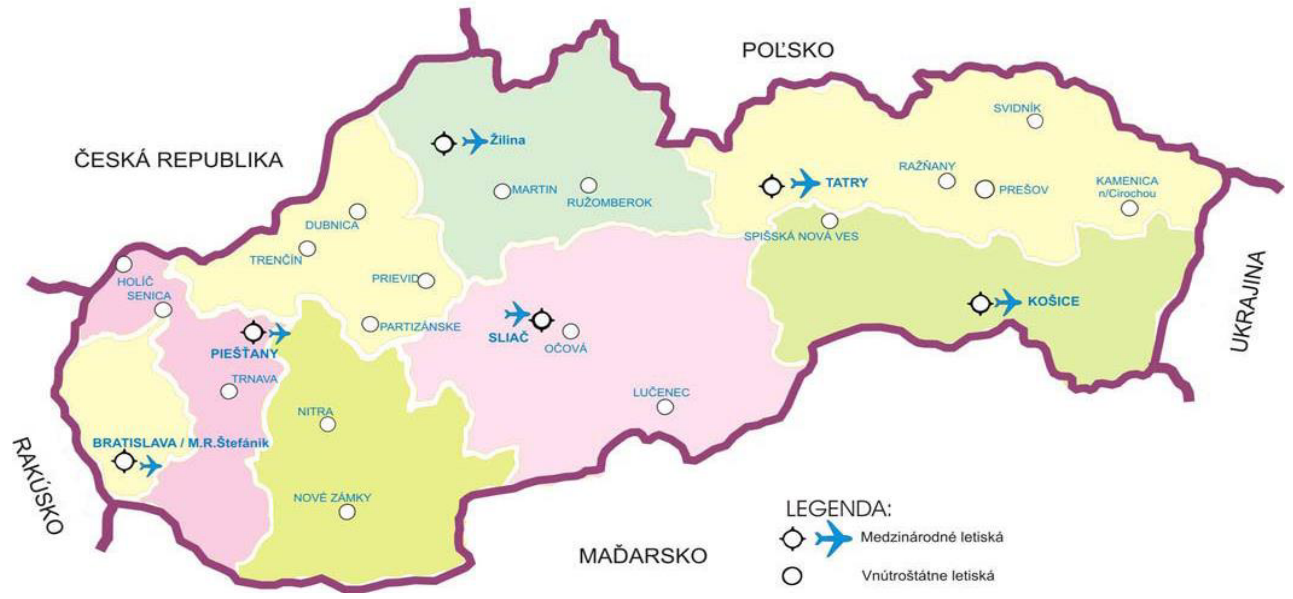

Fig. 1. Map of airports in Slovakia. Source: [7] 
By Resolution No. 130 from 2003, the Slovak Government approved the transformation of the Slovak Airport Administration, which operated 6 international airports, to 6 jointstock companies. Thus, separate legal units of individual airports with the participation of the State, higher territorial units and cities were created.

In line with the Convention on International Civil Aviation, Slovakia has accepted to guarantee compliance with ICAO standards and recommendations and to build the necessary civil aviation infrastructure. In April 2008 Slovak airports were divided into international (Bratislava, Košice, Poprad) and the so-called "Schengen area" airports (Sliač, Piešt'any, Žilina).

The main airport in Slovakia is M. R. Štefánik Airport in Bratislava. Its catchment area has the strongest demand, the above average growth and the highest economy's performance compared to other Slovak regions, as well as the highest GDP per capita. The existing potential of the airport catchment area is not utilized efficiently. Ensuring a regular connection to European metropolises could increase demand for air transport, especially business travellers prefer a sufficient frequency of flights at a favourable price in terms of time savings. The current airport runway allows landing of all commonly used aircrafts. Thanks to the modernization of ground handling services, infrastructure, sufficient capacity and technological equipment, it is possible to compare the airport with a European standard. The number of passengers proceed at the airport is shown in Table 3. Currently, there are operating ČSA, Ryanair, Wizz Air, Smartwings, Flydubai, Air Cairo, Pobeda, Georgian Airlines. The highest part of increase of passengers has the low-cost airline company Wizz Air [8].

Table 3. The number of passengers proceeded at Slovak airports. [6-9]

\begin{tabular}{|l|r|r|r|r|r|r|c|}
\hline $\begin{array}{l}\text { Airport } \\
\text { YYear }\end{array}$ & $\mathbf{2 0 0 0}$ & \multicolumn{1}{c|}{$\mathbf{2 0 0 5}$} & $\mathbf{2 0 1 0}$ & $\mathbf{2 0 1 5}$ & $\mathbf{2 0 1 6}$ & $\mathbf{2 0 1 7}$ & $\begin{array}{c}\text { Index } \\
\mathbf{2 0 1 7 / 2 0 0 5}\end{array}$ \\
\hline Bratislava & 283,714 & $1,326,493$ & $1,665,704$ & $1,564,311$ & $1,757,320$ & $1,942,069$ & 1.464 \\
Košice & 125,844 & 269,885 & 266,858 & 410,449 & 436,696 & 496,708 & 1.840 \\
Poprad & 12,780 & 18,335 & 28,961 & 85,224 & 84,030 & 80,600 & 4.396 \\
Piešt’any & 5,686 & 6,198 & 1,427 & 2,030 & 912 & 1,294 & 0.209 \\
Sliač & 1,534 & 18,149 & 0 & 35,682 & 36,682 & 22,511 & 1.240 \\
Žilina & 1,625 & 4,556 & 9,912 & 888 & 298 & 421 & 0.092 \\
\hline Total & 431,183 & $1,643,616$ & 1972862 & $2,098,584$ & $2,315,938$ & $2,543,603$ & 1.548 \\
\hline
\end{tabular}

The second most important airport in Slovakia is Košice Airport. Its catchment area appears to be the most stable. The airport takes advantage of its location on the east part of Slovakia, where the absence of the motorway connection to Bratislava persists as well as the poor competition of the surrounding airports (Poprad, Uzhhorod). To Košice airport, several airlines flights scheduled links like Austrian Airlines, ČSA, Eurowings, LOT Polish, Ryanair, Turkish Airlines and Wizz Air. In early 2018, the Hungarian low-cost company Wizz Air cancelled its base in Košice for economic reasons (similarly in the Czech Republic and Poland) and moved to London and Vienna. Because it is a low-cost company with limited resources, they need a place where it is economically more beneficial. It is still operating in Bratislava and providing flights to Košice [10].

The Poprad - Tatry Airport welcomes the highest number of passengers in incoming tourism especially during the winter tourist season (direct flights between Riga and Poprad). The scheduled air services are currently provided by Wizz Air (London - Luton), Air Baltic (Riga - Poprad) and non-scheduled air services from Poprad to Bulgaria, Turkey and Albania [11].

After modernization, the Sliač Airport is able to manage flights in outgoing tourism, similarly to Bratislava and Košice airports. There is a sufficient potential for outgoing tourism in the catchment area of the airport, but there is no tour operator to provide these services. The airport focuses only on non-scheduled flights in outgoing tourism. 
The Piešt'any Airport directly dependents on foreign demand for medical and spa treatment in the town of Piešt'any. The development of air transport to and from the airport of Pieštany is affected by the well-developed road transport infrastructure (the motorway network, 1st class roads, the railway network). The airport' runways has 2,000 m. Currently, the airport is without scheduled air services, operating only non-scheduled services for spa guests. In 2008, a departure terminal with a capacity of 150 passengers was reconstructed. An effort to maintain an airport that does not have the necessary economic performance is imposed by the city and the self-governing region.

The Žilina Airport is focused on providing air transport services to the region of northwest Slovakia. Compared to Pieštany Airport, there are other transport circumstances. The airport is not connected to the motorway network but there is sufficient demand for the air transport services in the catchment area. This creates the appropriate conditions for the entry of foreign capital. The length of airport runway $(1,150 \mathrm{~m})$ does not allow the landing of larger aircraft. It is mainly used for pilots training, sportsmen transport, incoming tourism, non-scheduled and private flights [12]. In 2005, the airport terminal was modernized and a scheduled flights Žilina - Prague were established by ČSA airlines. This connection was cancelled in August 2012. It was also reflected in the decline of passengers.

In 2017, Bratislava and Košice and Poprad-Tatry airports were provided scheduled national and international air transport. Domestic flights were only between Bratislava and Košice airports. Non-scheduled air transport service was provided from all Slovak international airports.

Between 2005 and 2017, the number of passengers proceed at Slovak international airports increased by 54.8\%. The Poprad - Tatry airport recorded the highest growth of numbers of transported people (almost 4.4 times), while Kosice Airport grew in $84 \%$ and Bratislava Airport $46.4 \%$. Of the Slovak-Schengen area airports, the number of passengers transported at Sliač airport increased positively (24\%) but Piešt'any and Žilina airports recorded a decrease. However, the potential of air transport from Slovakia has increased since 2005.

The absence of domestic national airline operator and flight connections to Slovakia mean that airline passengers traveling from and to Slovakia prefer nearby countries airports (Vienna, Prague, Budapest, Krakow). E.g. management of Bratislava Airport estimates that at present only Vienna Airport transported at least two million passengers from Slovakia annually [13]. They often leave in the morning and return that day. Passengers save money on accommodation, food and especially time. If the airport wants to attract business travellers, it must have at least two links a day in both directions. This is currently performed at Bratislava Airport but only some days to London. In Vienna, there are twelve daily flights to five London airports. These data demonstrate insufficient use of the existing air transport potential of Slovak airports.

\subsection{Investments in air transport infrastructure}

The investments in Slovak airports infrastructure included modernization of airports terminals (facilities, fuel depots, gates), improvement of security and service quality security and innovation of navigation equipment (Table 4). The Airports in Bratislava and Košice funded investments from their own resources, small airports from subsidies. Until 2030, the extension of landing and take-off areas for aircraft (Košice, Poprad, Žilina), the extension of the parking space for passenger vehicles (Poprad - Tatry, Žilina, Sliač) is planned. Additional investments are being considered in connection with the technical and operational status of the airport facilities [11].

Table 4. Investments and expenditures in airport infrastructure (Mil. EUR). Source: [11]. 


\begin{tabular}{|l|c|r|r|r|}
\hline Investment and expenditures/Year & $\mathbf{2 0 0 0}$ & $\mathbf{2 0 0 5}$ & $\mathbf{2 0 1 0}$ & $\mathbf{2 0 1 5}$ \\
\hline Investment in infrastructure & 3,6 & 27,5 & 70,1 & 4,2 \\
Expenditures in maintenance & 1,2 & 1,8 & 4,6 & 1,9 \\
\hline Total & 4,8 & 29,3 & 74,7 & 6,1 \\
\hline
\end{tabular}

The largest investments in the airport infrastructure were in 2010, when the highest spending per passenger was achieved (Table 5).

Table 5. Investments for one transported passenger. Source: [11].

\begin{tabular}{|l|c|c|c|c|}
\hline Year & $\mathbf{2 0 0 0}$ & $\mathbf{2 0 0 5}$ & $\mathbf{2 0 1 0}$ & $\mathbf{2 0 1 5}$ \\
\hline Investment and expenditures in Mil. EUR & 4,8 & 29,3 & 74,7 & 6,1 \\
Passengers in thous. & 429,6 & 1643,6 & 1971,8 & 2098,5 \\
\hline EUR/Passenger & 11,17 & 17,83 & 37,88 & 2,91 \\
\hline
\end{tabular}

Air transport has an impact on the country's economy, including tourism. It is also necessary to take into account possible negative impacts on the environment. This is primarily air emissions, aircraft noise and environmental pollution around airports. With the current volume of air transport in Slovakia, this situation does not burden the environment.

For the development of air transport, Slovakia has developed infrastructure (airports and ground facilities), which is barely used in tourism. In incoming tourism in 2016 [14], air transport was used mainly by tourists from more distant source markets (Russia 50\%, Germany $14.2 \%$, Ukraine 9.1\%), only small part from neighbouring countries (Poland $2.3 \%$, Czech Republic 1.6\%, Austria 1.4\%, Hungary 1.2\%). In outgoing tourism, up to $28 \%$ of Slovaks travelled by plane [15]. Air transport services to / from Slovakia are mainly provided by foreign airlines. In 2018, namely Czech Airlines, Ryanair, Austrian Airlines, Wizz Air, Turkish Airlines, Pobeda, Lot Polish Airlines, Fly Dubai, Georgian Airways, Air Baltic and Eurowings and Slovak non-scheduled airlines Travel Service, Air Explore and Go2Sky. In incoming tourism, the most used airports are Bratislava and Poprad - Tatry. It can be assumed that the Slovak air transport service will be used mainly in outgoing tourism. In domestic tourism, air transport is not used.

Connections that would link, for example, Bratislava or Košice airports with tourist centres (e.g. with Poprad-Tatry Airport) do not exist. This is mainly due to the short distances between individual airports, the time lost associated with the handling of passengers at airports as well as the competition of other modes of transport. For example, rail transport competes with air transport at its speed and cost of travel.

\section{Conclusion}

Transport infrastructure is one of the most important factors for a country's accessibility. Its role in promoting entrepreneurship in the regions is irreplaceable and, last but not least, is an important prerequisite for the development of tourism. Today in tourism, cars, rail and bus services are the most popular forms of transport in Slovakia. Air transport is mainly used in outgoing tourism, which is provided by foreign airlines.

After the establishment of the Slovak Republic, several companies started to provide air transport services to passengers at home and abroad. However, they did not have a long existence (about 8 to 10 years). The most common cause of their defunct were financial problems (inability to pay commitments to airports, contractors and insurance companies). Slovakia lacks mobility of the population and its own airline [1].

In terms of air transport infrastructure, Slovakia has 6 international airports (of which 3 Schengen), which in recent years have invested in the modernization of terminals, quality of services, safety devices, extension of take-off and landing areas. 
In order to make better use of existing air transport infrastructure in Slovakia, it is necessary to improve the transport accessibility of the country by creating connections and city pairs especially with European metropolises. Without a scheduled air transport service, Slovakia will remain only a transit country, respectively, the purpose of day trips of tourists arriving at Vienna, Budapest or Prague. If there is no direct connection, it is necessary to seek ways how to communicate with the airlines and to work more closely with incoming tour-operators [16].

At present, Slovak international airports are mainly used for non-scheduled air transport services in outgoing tourism provided by foreign airlines. The threat of terrorist attacks has also impact and discouraged a significant number of people from traveling to traditional destinations (e.g. Turkey, Tunisia, Egypt). The largest number of passengers in incoming tourism is recorded by Poprad - Tatry Airport.

Domestic tour-operators focus on outgoing tourism, which is more profitable than incoming tourism. That is why it is necessary to deepen the co-operation of domestic incoming tour-operators with airports in creating an offer for foreign visitors also from more distant markets.

\section{References}

1. J. Blažej, Trend, 19 (2017)

2. M. Ginieis, M. V. Sánchez-Rebull, F. Campa-Plans, Journal of Air Transport Management (2012)

3. M. Gúčik, Cestovný ruch (2017)

4. Koncepcia rozvoja leteckej dopravy Slovenskej republiky (2001)

5. Letecká doprava a cestovný ruch (Bratislava, 2004)

6. Letisko M. R. Štefánika, Ročná správa 2016 (Bratislava, 2017)

7. Letisko Poprad - Tatry, Výročná správa za rok 2016 (Poprad, 2017)

8. Letisková spoločnost’ Žilina, Výročná správa za rok 2016 (Žilina, 2017)

9. D. Michniak, Geografický časopis, 66 (2014)

10. Ministerstvo dopravy a výstavby SR (2018)

11. Strategický plán rozvoja dopravy SR do roku 2030 (2016)

12. Štatistický úrad SR (2016)

13. J. Tvardzík, Trend, 28 (2018)

14. Výročná správa letiska Poprad - Tatry (2015)

15. Základné ukazovatele za dovolenkové a služobné cesty v roku 2016 (Bratislava, 2017)

16. R. Kampf, O. Stopka, L. Bartuška a K. Zeman. Transport Means - Proceedings of the 19th International Scientific Conference on Transport Means. (Kaunas,Lithuania 2015). ISSN 1822-296X. 